\title{
THERMAL MINERAL WATER AS A NATURAL POTENTIAL FOR THE DEVELOPMENT OF SPA TOURISM IN BOSNIA AND HERZEGOVINA
}

\author{
Mevlida Operta ${ }^{1}$ \\ Amra Banda ${ }^{2}$
}

\begin{abstract}
Bosnia and Herzegovina is rich in natural resources, among which the most important are mineral, thermal and thermo-mineral waters. Heterogeneous and complex geological tectonics of Bosnia and Herzegovina conditioned emergence of the large number of mineral, thermal, thermomineral water springs that have a significant role in health care, spa and recreational tourism. Initiators of spa tourism in Bosnia and Herzegovina are spas. Healing power of thermal mineral springs has been recognized since the time of Greeks and Romans. After World War II visiting spas was more frequent, but in the period from 1948. to 1960., spas were treated as medical facilities. In the early 70 's, visiting spas was treated as a component of tourism, therefore hotels, restaurants and new rehabilitation centers were built. Modern life has influenced the transformation of the classic spa tourism which is increasingly getting the characteristics of wellness tourism. This paper presents some thermal mineral water in Bosnia and Herzegovina, which are valorized in spas, and registered as medical institutions. Besides them, there are numerous cases of these types of groundwater in our country whose value is still not recognized. Paper also describes problems of spa tourism offer, as well as possible ways of Bosnia and Herzegovina spa destinations improvment.
\end{abstract}

Key words: Bosnia and Herzegovina, mineral, thermal, thermal-mineral waters, spas, spa tourism.

\section{INTRODUCTION}

In the Federation of Bosnia and Herzegovina there are 163 deposition of mineral, thermal and thermo-mineral waters. Most common are reservoirs of mineral waters (101), followed by deposition of thermal water (39) and at least represented are thermal mineral depositions (23). According to the level of research thermal mineral water with temperature of less than $40^{\circ} \mathrm{C}$ are better explored. Although in Bosnia and Herzegovina in the last 50 years intensified research of numerous deposits of thermal and mineral waters were taken, level of research is not satisfactory.

This paper aims to define the main characteristics of the spa tourism in Bosnia and Herzegovina, which is traditionally an important part of the national tourism market, due to the important resources discovered and valued since antique time and developed to the dimensions of a tourism industry during history, which tries to adapt to new market realities.

On the territory of Bosnia and Herzegovina usage of thermal springs for the purpose of therapeutic activities dates back to the Greeks and Romans. It is known that the Romans used thermal springs of almost all today known spas.

Roman coins which were given for health were excavated in Banja Vrućica near Teslić. Thermal mineral water Guber is also known since the ancient Romans period who called it springs Domavija, and the whole area Argentaria. Proof of this is the inscription on the ruins of the spa from the Roman period.

\footnotetext{
${ }^{1}$ Associate Professor, Department of Geography, Faculty of Science, University of Sarajevo, Sarajevo, Bosnia and Herzegovina.

${ }^{2}$ Teaching Assistant, Department of Geography, Faculty of Science, University of Sarajevo, Sarajevo, Bosnia and Herzegovina.
} 
First traces of the usage of thermal water Ilidža near Sarajevo, dates back to the Roman period who built first spa in Ilidža, as evidenced by the Roman excavations. The biggest development Ilidža experienced in the Austro-Hungarian period. From 1878. to 1895. new accommodation facilities were built. Ilidza had several objects: Stara banja (Old Spa), Nova banja (New Spa), Mala banja (Little Spa) and Blatna banja (Mud Spa). Stara banja had a room for relaxation, two large new pools, Mala banja had cabins for handicapped person and there was also a clinic, balneological infirmary with the application of physical, hydro, electric therapy, sauna and etc. First data about the thermal mineral water in Ilidza gave Mojsisovics, Bittner and Tietze in 1880., and Ludwig did the first chemical analysis of the thermal mineral water Ilidza in 1886. and second in 1894. Ilidza municipality is named after the Turkish word "iladž" which means medicine, or what gives man life.

Roman legionaries healed their wounds in the waters of Fojnica, so the Austro-Hungarian officers and officials treated rheumatism in Fojnica spa. In 1948. they build a hotel, which gradually became a modern institution named "Reumal" for rehabilitation, recreation and relaxation. First analysis of the thermal water in Fojnica was done by E. Ludwig in 1888. so the folk tradition about the healing characteristics of the water got scientific confirmation.

First written documents about the healing characteristics of water in Kiseljak originate from ancient times the 14 th century.

In the period from 1948. to 1960, after World War II, visiting spas in Bosnia and Herzegovina became popular so the spas were treated as a medical facilites. In the early 70 's visiting spas was treated as a tourism component and accordingly to this fact hotels, restaurants and new rehabilitation centers were built. Spa tourism tradition in Bosnia and Herzegovina as well as in the world expands as new facilities in the spa resorts such as massage centers, fitness, physiotherapy and others are introduced. This paper also underlines the meaning of spa tourism, as a continuous multiphase paradigm, influenced by modern patterns of tourism consume and analyses tourist offer in the most important spa and healing centers in Bosnia and Herzegovina.

\section{STAKEHOLDERS OF BALNEOLOGICAL TOURISM IN BOSNIA AND HERZEGOVINA}

Modern spa industry is mainly based on the use of natural resources ie thermal mineral waters and healthy climate combined with medical care and therapeutic activities. Existence of spa resorts is "in part related to the availability of suitable natural resources including mineral springs or attractive amenity landscapes or climate" (Hudson, 2003). The main function of spa tourism resorts is to provide health care service by using natural factors for medical cure in specialized structures and a pleasant environment. (Erdeli et al, 2011) Stakeholders of balneological tourism in Bosnia and Herzegovina are spa-centers. In Bosnia and Herzegovina there is a larger number of balneological centers, with different level of tourist affirmation, registered as health institutions. In this paper some of them are presented.

Spa Terme Ilidža near Sarajevo is located at the foothill of Igman mountain, near the spring of the river Bosnia. Thermal water of Ilidža by water temperature belongs to hyperthermal waters and to the hydro-sulphate-calcium-sodium type. Terme Ilidža stopped working in 1992., and after the reconstruction of the hotel more sophisticated and better equipped resort revived in 2004. This resort has 400 beds, conference halls, restaurant and a cocktail bar. Spa has modern equipment and medical staff for: hydrotherapy, two 
therapeutic-recreational pools, physical therapy (electrotherapy, ultrasound therapy, thermotherapy, magnetic therapy, kinetictherapy etc.) and wellness program (solarium, fitness room, two indoor swimming pools and a Turkish bath ). According to previous research thermal mineral water of spa Ilidža, can be used to treat patients with rheumatic diseases, joint and bones diseases, chronic inflammation of the lining, catarrh, disease of the nervous system, damage of the blood circulation, as well as gynecological diseases, endocrine disorders and some skin diseases. Inhalation is used in chronic inflammation of the respiratory tract. Terme Ildiža offers its visitors tour of the city with a professional guide, a trip to the spring of river Bosna, folklor evenings with national specialties, as well as skiing, hiking, walking tours and other recreational activities.

Banja (Spa) Vrućica is located 3 kilometers from Teslić. Due to a water temperature of $37.5^{\circ} \mathrm{C}$ this water is classified as a homeothermal water, ie chloride- hydrocarbonatechloride-calcium-sodium type. (Tab. 1.) Water of Banja Vrućica is used for the following treatment: myocardial infarction, angina pectoris, hypertension, rheumatic diseases, diseases of the pancreas and liver, bronchitis and others. Spa in its complex has 4 hotels and about 900 beds and provides prevention, treatment and rehabilitation of patients. Banja Vrućica organizes congresses, conferences, seminars, business and other meetings, recreational activities in the bowling alley, at the sports terrains and fitness center. Wellness program has several swimming pools and several saunas.

Banja (Spa) Aquaterm is located in the town Olovo. In the Krivaja river valley is registered about 10 thermal springs (Terma, Solun, Očevija, Orlja etc.) with similar physico-chemical and genetic characteristics. Thermal waters Olova and Orlje are used in recreational and medicinal purposes. Thermal waters of Solun has not yet been valorized in tourism, and there are no accommodation capacities nearby. Water temperature in the healthrehabilitation center Aquaterm Olovo is $34.5^{\circ} \mathrm{C}$, and by the chemical characteristics is classified as hydrocarbon-calcium-magnesium water type. (Tab. 1.) Center of balneological tourism in municipality Olovo is a health and rehabilitation center "Aquaterm" which provides medical and rehabilitation services. Center has 160 beds in double and triple rooms. Facility has a TV lounge, billiards salon, game room (chess, dominoes, etc.), table tennis etc. Program of spa treatment includes: hydrotherapy (baths, underwater massage, pool), thermotherapy (paraffin, cold compresses) and electrotherapy. In spa and recreational area of the hotel are located baths with thermal water as well as massage areas. Thermal water in Olovo treats: rheumatism, arthritis, spondylosis, central nervous system diseases, infertility, psoriasis and others. 
Tab. 1. Temperature and hydrochemical type of some mineral and thermal mineral water in Bosnia and Herzegovina.

\begin{tabular}{|l|l|l|}
\hline \multicolumn{1}{|c|}{ Locality } & Water temp. $\left({ }^{\circ} \mathbf{C}\right)$ & \multicolumn{1}{c|}{ Water type } \\
\hline Ilidža-Sarajevo & 57 & Hydrocarbonate-sulphate-calcium-sodium \\
\hline Dvorovi-Bijeljina & 56 & Chloride-hydrocarbonate-sodium \\
\hline Slatina-Banjaluka & 40,7 & Sulphate-hydrocarbonate-calcium-magnesium \\
\hline Banja Vrućica-Teslić & 37,5 & The hydro-chloride-calcium-sodium \\
\hline Gračanica & 37 & Hydrocarbonate-sulphate-sodium-calcium \\
\hline Gata-Bihać & 36 & Sulphate-chloride-calcium-sodium \\
\hline Olovo & 34,5 & Hydrocarbonate-calcium-magnesium \\
\hline Višegrad & 34,2 & Hydrocarbonate-calcium-sodium \\
\hline Gornji Šeher-Banjaluka & 34 & Hydrocarbonate-sulphate-calcium-magnesium \\
\hline Laktaši & 30 & Hydrocarbonate-calcium-magnesium \\
\hline Kulaši-Prnjavor & 30 & Hydrocarbonate-chloride-sodium-calcium \\
\hline Tomina Ilidža-Sanski Most & 29 & The hydro-chloride \\
\hline Fojnica & 28,9 & Hydrocarbonate-calcium-magnesium \\
\hline Ilidža-Gradačac & 28,3 & Hydrocarbonate-sulphate-sodium-magnesium \\
\hline Slana banja-Tuzla & 27 & Chloride-sodium \\
\hline Mlječanica-Kozarska Dubica & 14 & Hydrocarbonate-sulphate-calcium-sodium \\
\hline Crni Guber - Srebrenica & 12,4 & Iron-arsenic \\
\hline Kiseljak-Kiseljak & 12,2 & Hydrocarbonate-sulphate-calcium-sodium \\
\hline
\end{tabular}

Source: Josipović, (1971), own tabular presentation

Banja (Spa) Reumal near Fojnica, is located $50 \mathrm{~km}$ from Sarajevo. Thermal water of Fojnica is classified as hydrocarbonate-calcium-magnesium type, and by temperature characteristics it belongs to hypothermal water. This is nitrogen and radon water, which contains traces of some elements (lithium, strontium, rubidium, etc.) that have medical effect. Reumal has center for physical therapy as well as newest equipment for physical medicine and rehabilitation in Federation of Bosnia and Herzegovina and beyond. Today, Fojnica with its enviable accommodation and decades-long tradition has a leading position in the field of spa tourism in Bosnia and Herzegovina. Reumal for its visitors organizes various events: theater performances, book presentations, visits to museums etc. This center is also a co-organizer of various sport events and excursions to natural, cultural and historical sights of Fojnica.

Banja (Spa) Ilidža in Gradačac is located in the Northern Bosnia about $1.5 \mathrm{~km}$ from Gradačac. Thermal water in the spa is classified as hydro-sulphate-sodium-magnesium and is slightly radioactive. The water temperature is $28.3^{\circ} \mathrm{C}$. Center for physical medicine, rehabilitation and spa treatment "Ilidža" in Gradačac was built in 1980. and it has 150 beds in double, triple rooms and apartments. Congress tourism can also be developed, because this facility has a conference hall with 470 seats. Water of Ilidža Gradačac successfully treats rheumatic diseases, neurological diseases, injuries, diabetes, and gynecological diseases. 
Banja (Spa) Guber is located in the area of Northern Bosnia, about $2.5 \mathrm{~km}$ from Srebrenica. All 5 sources of mineral water in the area of Srebrenica (Veliki Guber, Mali Guber, Crvena Rijeka etc.). spring from igneous rocks. Bottling of Guber water started in 1889.. Water of Crni Guber contains an essential component of bivalent Fe and rare elements: copper, cobalt, nickel and manganese, as well as many others that together create this healing combination. Water temperature is $12.4{ }^{\circ} \mathrm{C}$. In the area of Spa Guber there are also several mineral springs. Water of Crni Guber is successfully used to treat: anemia, , chronic skin diseases, rheumatism and for weight problems.

Banja (Spa) Dvorovi is located in the area of Northern Bosnia, northeast of city Bijeljina.

Based on the data obtained by deep drilling, tested interval from which thermal mineral water of Spa Dvorovi springs are made of sand and clay marl and sandstone to a depth of about 1176 m. (Đurić, Radovanović, 2012).

Thermal water of Spa Dvorovi by water temperature belongs to hyper thermal waters and by its composition to the chloride-hydrocarbonate-sodium type (Table 1). This spa offers all kinds of massages, inhalation, acupuncture and successfully treats the following diseases: chronic rheumatic diseases, mild forms of diabetes, chronic gastritis, limb injuries.

\section{PROBLEMS OF HEALTH-REHABILITATION CENTERS}

In Bosnia and Herzegovina the term spa is still tied for the treatment of patients. Tourist visit to spas for rest and entertainment is not present in Bosnia and Herzegovina as it is in the world. As a result, visitors are mainly elderly people. Key issues that are present in some health-rehabilitation centers have limited capacity or lack of accommodations, as well as the need for their expansion.

Banja (Spa) Terme in Gračanica does not have its own accommodation facilities so the visitors stay in hotels in the city and its surroundings. Same situation is in the Banja (Spa) Tomina Ilidža for which is planned to become a health - recreation center Sanska Ilidža, with supporting facilities. Salt Spa (Slana banja) in Tuzla is currently not in use because new Hotel Bristol within which is planned shopping center and offices, clinics with a wellness center, saltwater pool and an Olympic swimming pool is built. For the purposes of Banja (Spa) Guber in 1967. hotel Domavija was built and motel on the Guber spring was refurbished. Spa center for physical medicine, rehabilitation and spa treatment Argentaria was built in 1982. Currently these facilities are not in use because most of the infrastructure was destroyed in the war 1992. - 1995.

Motel Vrelo disposed with 20 beds and a restaurant, and hotel Domavija with 113 accommodation facilities and 244 beds, but they are both not in use since 1992 .

Banja (Spa) Aquaterm in Olovo did business until 1991. within the Sarajevo Brewery. Since 2001., it is registered as a public health institution. Rooms were renovated and accommodation capacities were expanded and additional medical personnel hired. Still, it is necessary to renovate facilities for medical treatment and to build another indoor and large outdoor swimming pool. 


\section{WAYS OF IMPROVING TOURIST OFFER OF REHABILITATION CENTERS}

Key issue for some spa centers is the lack of additional tourist offer. Tourist offer of spa could be improved and enriched with new contents. For example, Banja (Spa) Ilidža Gradačac can offer day trips to cultural and historical sights such as the Castle of the Husein captain Gradaščević from the 18th century, Husejnija mosque that was built in 1826 and the Clock Tower from 1824, and events such as the Plum Fair.

Banja Vrućica can combine its tourist offer with other attractive tourist attractions in Teslić, such as winter-sports center Hajdučke vode on the mountain Borja, tours to Liplje monastery from the 13th century, visits to Rastuške caves, Teslic city tours etc..

In addition to the spa rehabilitation, Višegrad spa as organizer can offer visitors additional attraction as for example walking the slopes of Tara, Drina River cruise, ride on the restored railroad Mokra Gora-Visegrad, visit to ethno village Mećavnik and visits to religious, artistic and historical treasure of this region.

Slana Banja (Salt Spa) in Tuzla for their visitors can arrange excursions to natural, cultural and historical sights. Area of Tuzla Municipality provides an opportunity for excursion trips. A significant part of the tourist offer is resort Ilinčica, Pannonian lakes and salt exploitation wells.

As for the offer of "Aquaterm" in the future, it should be pointed out that the key problem is the lack of additional offers and content. This deficiency can be eliminated if the offer of health and rehabilitation center would combined with visits to nearby places (Zeleni vir, Solun, Kamenica, Bjeliš Bijambare etc.) or with the organization of cultural events.

Area of the Olovo Municipality is rich with surface waters. Rivers Bioštica, Stupčanica and Krivaja are suitable for excursions, and provide an opportunity for organizing rafting tours. Several sites of cultural and historical monuments are located in Olovo Municipality Visit to monuments such as stećci (medieval tombstones) can be complementary activity to basic offer of health and rehabilitation center Aquaterm.

Banja Reumal for its visitors organizes various events: theater performances, book presentations, lectures, visits to museums etc. This center is also a co-organizer of various sport events and day excursions to natural, cultural and historical sights of Fojnica. Reumal can organize visits to the Franciscan monastery in Fojnica and excursions to Prokoško lake which is located on the mountain Vranica, and is known for its endemic species of flora and fauna, such as triton. The Franciscan monastery has a rich museum collection of minerals and rocks samples, ancient annals, incunabula, books, pictures and charters in Bosnian Cyrillic, Arabic, Turkish, Persian, Latin etc.

In order to improve spa tourism offer in Bosnia and Herzegovina it is important to choose one or more potential tourist segments for this tourism sector and to elaborate strategy based on market research and analyses of tourist offer from neighbour states.

Spa tourism in Bosnia and Herzegovina, as well as many other tourism sectors is still mainly dominated by socialism structures, and spa tourism offer is attractive for domestic tourists due to social balneal culture and social insurance systems. Mentioned spa centers in Bosnia and Herzegovina offer tourist arrangement within their facilities and yre trying to develop additional leisure infrastructure, organize field trips, sports events in the attempt to attract more tourist, not just seniors. Bosnian spa centers also need to consider development of rehabilitation cures and spa packages. 


\section{CONCLUSION}

Mineral, thermal and thermal mineral waters of Bosnia and Herzegovina have a wide range of application in balneology, medicine, recreation, sports, tourism, bottled water industry, salt and gas extraction from water, water supply and etc.

In Bosnia and Herzegovina, Reumal and Vrućica near Teslić stand out by the number of overnights. Much smaller number of overnights stays is registered in spas: Slatina near Laktasi, Ilidža in Gradačac Aquaterm in Olovo and Mlječanica in Kozarska Dubica. Current level of spa tourist valorization in Bosnia and Herzegovina is not satisfactory. Faster development of spa tourism, implies greater investment in the facilities construction, as well as the enrichment of the offer and a well designed marketing. In Bosnia and Herzegovina term spa is still connected to the treatment of patients and tourist trip to spas for rest, recreation and entertainment is not represented as it is in the world. This is one of the reasons why the spas are mainly visited by seniors who come for treatment.

Tourist capacities of spas in Bosnia and Herzegovina are not used properly. It is necessary to invest in the development of the existing spa centers (expanding facilities such as fitness and wellness services) and in construction of new recreation centers. In addition, marketing activities should be improved and in particular Internet presentation of the spa centres.

Spa tourism sector in Bosnia and Herzegovina in the last two decades transformed by the political and socio-economic changes, but is still dominated by elements from the socialist period that was characterized by mass tourism and mass accomodatian structures. Spa centers in Bosnia and Herzegovina try to adapt to new market trend and forms of spa tourism and orient itself towards international tourism trends and patterns.

\section{REFERENCES}

1. Đurić, N., Radovanović, S. (2012): Energetska potencijalnost geotermalnih resursa i mogućnost njihovog korištenja za toplifikaciju grada Bijeljina. Arhiv za tehničke nauke $b r$. 6, Tehnički institut Bijeljina, p. 1-9

2. Erdeli, g., Dincă, A. I., Gheorghilaş, A. Surugiu, C. (2011): Romanian spa tourism: a communist paradigm in a post communist era. Human Geographies - Journal of Studies and Research in Human Geography, (2011) 5 . 2, 41-56

3. Hudson, S (2003): Sport and Adventure Tourism, The Haworth Hospitality Press, New York

4. Josipović, J. (1971.): Mineralne, termalne i termomineralne vode na teritoriji Bosne i Hercegovine, Geološki glasnik knjiga 15., p. 233-275. Sarajevo.

5. Katzer, F. (1919.): K poznavanju mineralnih vrela Bosne, Glasnik Zemaljskog muzeja BiH, p.191-264, Zemaljska štamparija,Sarajevo

6. Kubat I., (1966.): Problem rudarenja i određivanja zaštitnog polja mineralnog vrela Veliki (Crni) Guber kod rudnika „Srebrenice“ u istočnoj Bosni, Geološki glasnik 11., Sarajevo, str. 289-301.

7. Ludvig, E. (1893.): Mineralni izvori u Bosni, Geološki anali Balkanskog poluostrva, knjiga. IV, p. 244-278., Beograd.

8. Miošić,N. (2000.): Podzemne, pitke, mineralne, termalne i termomineralne vode Unsko-sanskog kantona, Bilten Speleološkog društva "NAŠ KR ̌́" XX - XXI, p.33 34, Sarajevo. 
9. Skopljak F., (2006.): Odnosi podzemnih voda područja Ilidže kod Sarajeva, Posebna izdanja geološkog glasnika, knjiga XXIX, Sarajevo.

10. http://www.espa-ehv.eu/ (Accessed 27.08.2015.) 